\title{
Analysis of Soil Heavy Metal Pollution and Investigation of Dominant Plants in Abandon Gold Ming Area
}

\section{Rui Chen}

Chang'an University

Lei Han ( $\square$ hanshuanglei@chd.edu.cn )

Chang'an University

Zhao Liu

Chang'an University

Yonghua Zhao

Chang'an University

\section{Shanshan Chang}

Chang'an University

\section{Leshi Li}

Chang'an University

\section{Risheng Li}

Shaanxi Provincial Land Engineering Construction Group

\section{Longfei Xia}

Shaanxi Provincial Land Engineering Construction Group

\section{Research Article}

Keywords: abandon mining area, soil arsenic pollution, potential ecological risk assessment, dominant plants, enrichment characteristics, phytoremediation

Posted Date: November 1st, 2021

DOl: https://doi.org/10.21203/rs.3.rs-989037/v1

License: (c) (i) This work is licensed under a Creative Commons Attribution 4.0 International License. Read Full License

Version of Record: A version of this preprint was published at Minerals on October 27th, 2022. See the published version at https://doi.org/10.3390/min12111366. 
Analysis of Soil Heavy Metal Pollution and Investigation of Dominant Plants in Abandon Gold Ming Area

Rui Chen ${ }^{1,2}$, Lei Han ${ }^{1,3,4}$, Zhao Liu ${ }^{3,4}$, Yonghua Zhao ${ }^{3,4}$, Shanshan Chang ${ }^{3}$, Leshi Li ${ }^{3}$, Risheng Li ${ }^{5}$, Longfei Xia ${ }^{5}$

1 Key Laboratory of Degraded and Unused Land Consolidation Engineering, Ministry of Natural Resources of the People's Republic of China, Xi'an 710054, China

2 School of Earth Sciences and Resources, Chang'an University, Xi'an 710054, China;

3 School of Land Engineering, Chang'an University, Xi'an 710054, China;

4 Shaanxi Key Laboratory of Land consolidation, Xi'an 710054, China

5 Shaanxi Provincial Land Engineering Construction Group, Xi'an 710075, China;

* Correspondence: hanshuanglei@chd.edu.cn (L.H.)

\section{Highlights:}

1. Evaluation of soil arsenic pollution degree in abandoned mining area

2. Vegetation composition characteristics of abandoned mining area

3. Arsenic enrichment characteristics of plants in abandoned mining areas

4. Screening arsenic-tolerant plants suitable for the local climate environment

Abstract: In recent years, environmental pollution and ecological destruction in mining area has seriously affected the health and survival of surrounding people. To explore the degree of heavy metal pollution in soil of mining areas and phytoremediation strategies, we chose soil and dominant plants in an abandoned gold mining area as the research object. In this study, Arsenic (As) content in soil and plants was measured. The As pollution degree in local areas was evaluated by using geoaccumulation index and potential ecological risk index. And, As content in plants was analyzed by using enrichment coefficient method. The results show that 1) The pulp deposition area has the most serious As pollution of soil and the largest potential ecological risk index. 2) The composition of the plant community in the study area is dominated by herbaceous plants, among which gramineous, composites and legumes are the dominant plant types in the vegetation community restoration in the mining area. 3) The geoaccumulation index is significantly negatively correlated with species diversity index, Shannon-wiener diversity index and Pielou species evenness index. 4) The As content in dominant plants ranges from 0.11 to $15.92 \mathrm{mg} / \mathrm{kg}$. The plants with strong As enrichment ability are Erigeron annuus (L.) Pers., Periploca sepium Bunge, and Setaria viridis (L.) Beauv., which can be considered as As-tolerant plants. This study can provide a basis and reference for plant management of As pollution in local soil.

Key words: abandon mining area; soil arsenic pollution; potential ecological risk assessment; dominant plants; enrichment characteristics; phytoremediation

\section{Introduction}

Tailings have always been one of the main sources of environmental pollution caused by mining, especially metal mining (Wang et al. 2018). The mining of minerals will lead to the diffusion of toxic elements in the environment (Luo et al.2021; Deng et al. 2019). When these minerals are mined, heavy metal elements are transferred from the depths of the earth to the surface. As a result, their geochemical conditions are changed, become very active, and redistribute on the surface, 
which leads to an increased arsenic concentration in local areas (Xiao et al. 2001) and causes heavy metal pollution in soil. As is a common element in Carlin-type gold deposits which is a gray metal known as elemental As or metallic As. It is a non-essential element for the human body. As is highly toxic and carcinogenic. There are few natural As or As metal compounds in nature, and most of them are mixed in the form of sulfide in gold, copper, lead, zinc, tin, nickel, and cobalt mine. Therefore, strengthening the comprehensive management of the mine environment is a common concern of all countries in the world. The basis of heavy metal pollution control of soil is the identification of pollution characteristics and environmental risk assessment (Bourliva et al. 2017). Besides, the evaluation of the degree of heavy metal pollution is of great significance to the protection of human health, soil and ecological environment (Liang et al. 2018). Meanwhile, the investigation and evaluation of the pollution degree of heavy metal contaminated soil are helpful to understand the soil pollution status in the area (Yuan et al. 2021), and provide a useful reference for the treatment and prevention of heavy metal pollution of soil.

As is extremely harmful to humans and higher animals (Alka et al.2020; Zheng et al. 2020b), and poses a serious threat to the ecological environment. Therefore, the restoration of Ascontaminated soil is an urgent problem to be solved. Plants can absorb As in soil and accumulate it in their bodies, especially plants growing in arsenic-contaminated areas have strong tolerance to arsenic pollution and can transfer heavy metal arsenic in soil. Phytoremediation technology is an insitu restoration technology. After the vegetation appeared, it can not only protect the surface soil, but also reduce water and soil erosion. It can be applied to vegetation and landscape restoration of heavy metal contaminated sites and the reclamation of mines (Manoj et al. 2020). Hyperaccumulator plants have been widely used in heavy metal restoration research due to their remarkable ability to enrich, transfer and tolerate heavy metals. At present, the internationally reported As hyperaccumulators mainly include Pteris vittata L. (Ma et al. 2020; Chen et al 2002), Pityrogramma calomelanos (L.) (Meharg. 2003), Pteris cretica L.var.laeta (Wall.)C.Chr.et Tard. -Blot [P. laete Wall.] (Wei et al. 2002), Pteris cretica L. var. nervosa (Thunb.) Ching et S. H. Wu (Yan et al. 2019), P. ryukyuensis (Srivastava et al. 2006) etc. However, most of these plants live in areas with sufficient water and are not suitable for areas where water resources are scarce. So, it is very important to select As-tolerant plants whose habitat characteristics are compatible with the local environment. In addition, due to the limitations of hyperaccumulator, researchers currently have begun to pay attention to ordinary plants with great vitality, wide adaptability, and large aboveground biomass. Various biological, chemical and physical measures are taken to increase the effectiveness of heavy metals in the soil to arouse and strengthen the absorption of heavy metals by such plants (Zhang et al. 2019). For example, Cyperus papyrus L.( Nateewattana et al. 2011), Buddleja officinalis Maxim., Anaphalis margaritacea (L.) Benth. et Hook. f., Amaranthus Paniculatus L. (Rodriguez-Lado L et al. 2013), willos (Zou et al. 2004) have also been shown to be resistant to As, which provides abundant species resources for phytoremediation of As-contaminated soil. As-tolerant plants usually grow around As-contaminated fields. Although these enriched plants do not have the superabsorption and enrichment capacity of ferns such as Pteris vittata L., their habitat characteristics are compatible with the local environment, and they also have application value for the remediation of local As-contaminated soil. Thus, investigating plants on As-contaminated fields is one of the effective ways to find As-tolerant plants that are compatible with the local environment. In this paper, through field sampling and experimental analysis, the As content of the soil in the mining area was investigated and analyzed, and the pollution level was evaluated. Also, the relationship 
between the degree of soil As pollution and vegetation composition and plant diversity was discussed. This study can provide a theoretical basis and suggestions for the treatment and restoration of As-contaminated soil, the improvement of the local ecological environment, and the construction of beautiful and livable villages.

\section{Materials and methods}

\subsection{Study area}

Shangluo City is located in the southeastern part of Shaanxi Province, China. It is between $108^{\circ} 34^{\prime} 20^{\prime \prime}-111^{\circ} 1^{\prime} 25^{\prime \prime} \mathrm{E}$ and $33^{\circ} 2^{\prime} 30^{\prime \prime}-34^{\circ} 24^{\prime} 40^{\prime \prime} \mathrm{N}$. The total area is 19,851 square kilometers, whose geographical distribution is in the junction area of the northern subtropical and warm temperate zone. In the horizontal direction, there are transitional characteristics of two climatic zones, the southern part has a northern subtropical climate and the northern part has a warm temperate climate. The annual average temperature is $7.8-13.9^{\circ} \mathrm{C}$, the annual average precipitation is $696.8-830.1 \mathrm{~mm}$, and the annual average sunshine duration is 1848.1-2055.8 hours. Shangluo's terrain is complex, with large differences in elevation and vertical height, and has obvious threedimensional mountain climate characteristics. There are obvious differences in light, heat, water, climate resources and meteorological disasters in various places, and their distribution is extremely uneven. The soil type in the south of Shangluo City is yellow cinnamon soil, and the north is mainly cinnamon soil. The Gold Production Company in research area operated in 1993. In 2006, the "4.30" dam failure occurred. In 2016, Shangluo City's first comprehensive treatment project for heavy metal pollution in farmland soil was launched. The project adopted "microorganism + phytoremediation" technology for heavy metal pollution in farmland soil, and for exposed waste slag, embraced "slag removal + screening/solidification stabilization repair + safe filling Buried" process. After the project was completed, the final site would be recovered and the vegetation would be restored. The project was completed in 2018 .

\subsection{Acquisition and processing of soil data}

According to the results of previous field investigations, the As content in soil in the mining area is mainly affected by human activities and shows a large difference. 50 soil samples $(0-20 \mathrm{~cm})$ were collected based on the uniform grid method with a high sampling density in the mining area $(50 \mathrm{~m})$. There were three members in the research group with unified training on the sampling method. A real-time kinematic (RTK) was used to precisely locate every sampling location. Figure 1 shows the position of the sampling points. Stones, plant residues, and other large debris were removed from each fresh sample, which was then mixed thoroughly and then stored in a labeled plastic bag. Each sample weighed $500 \mathrm{~g}$. All samples were air-dried at room temperature. Small stones and plant residuals were manually removed and the soil samples were then run through a $0.15 \mathrm{~mm}$ sieve. The samples were divided into two parts, one was used for chemical determination of $\mathrm{pH}$ and soil As content, the other was sealed for backup. As content in the soil was determined by the atomic fluorescence spectrometry method; the $\mathrm{pH}$ value of the soil was measured by the glass electrode method.

There were 27 vegetation survey samples of 16 square meters $(4 \mathrm{~m} * 4 \mathrm{~m})$ set up to investigated the composite of the plants. We used TRK to record the center point coordinates of the sampling party, and the sampling location is shown in Figure 1. We measured the number and average height of each plant in the sample square, and collected the dominant plants. The names of the collected plants are shown in Table 1. The plant samples dried naturally after being washed. After 30 minutes 
of deactivation of fixating at $105^{\circ} \mathrm{C}$, they were weighed to constant weight at $80^{\circ} \mathrm{C}$, crushed and passed through a 60-mesh nylon sieve. Plant As content was determined by an atomic fluorescence spectrometer.
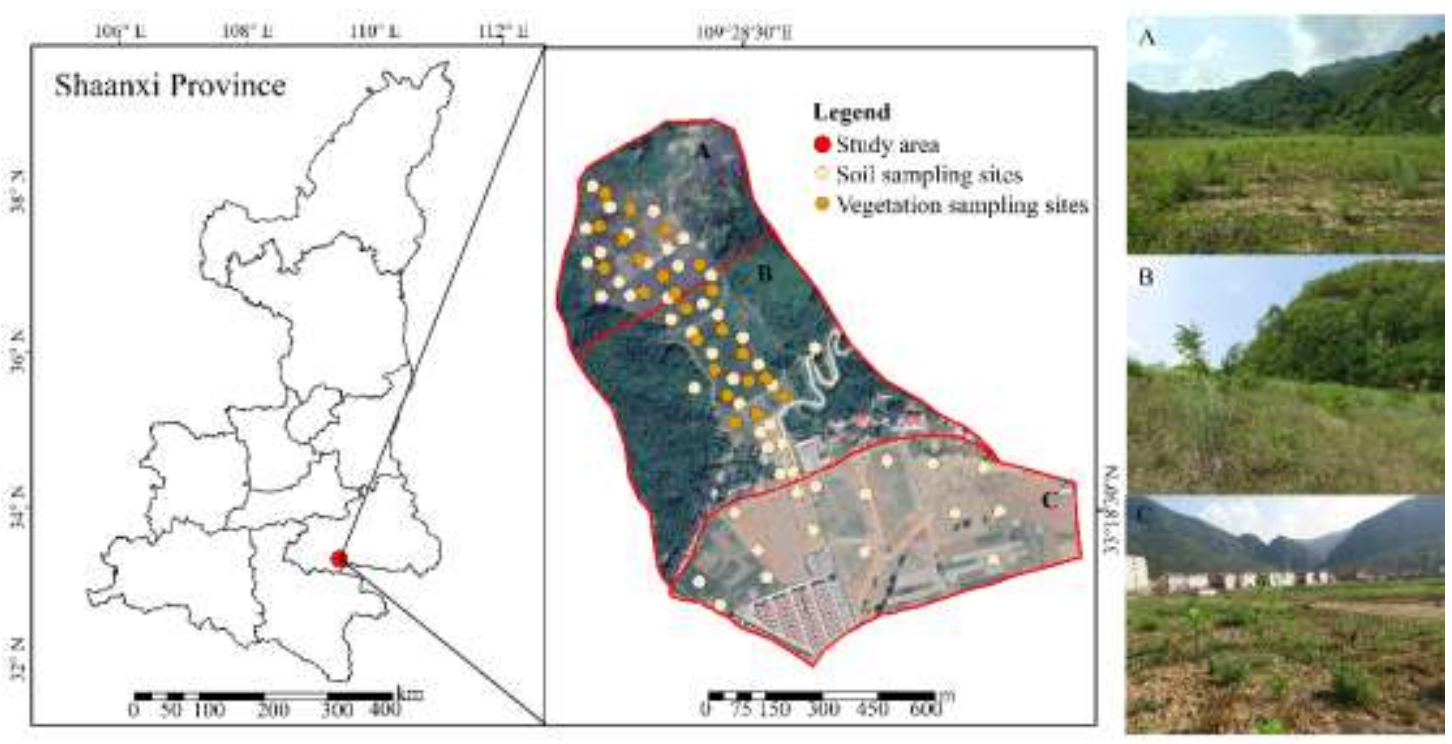

Figure.1 Study area and the distribution of soil sampling points; A-C denote six types of land use, the pulp deposition area (A), the hillside (B), and the remediation field (C).

Table1 Sampling area and sample types

\begin{tabular}{ll}
\hline Sampling area & Types of samples collected \\
\hline the pulp & Soil samples, Periploca sepium Bunge, Robinia pseudoacacia L, \\
deposition area & Phragmites communis (Cav.) Trin. ex Steud., Setaria viridis(L.) Beauv., \\
(A) & Imperata cylindrical (L.) Beauv., Erigeron annuus(L.) Pers. \\
the hillside (B) & Soil samples, Ailanthus altissima, Macleaya cordata (Willd.) R. Br., \\
& Periploca sepium Bunge, Medicago Sativa Linn, Erigeron annuus (L.) \\
& Pers., Aster subulatus Michx., Solanum nigrum L., Digitaria sanguinalis \\
& (L.) Scop., Polygonum L, Chenopodium album L. \\
\hline
\end{tabular}

\subsection{Evaluation of Pollution Degree}

\subsubsection{Index of geoaccumulation}

The geoaccumulation index (Müller. 1969) $\left(I_{\text {geo }}\right)$ can not only reflect the natural change characteristics of the distribution of heavy metals, but also judge the impact of human activities on the environment. Calculated as follows:

$$
I_{\text {geo }}=\log _{2}\left(C_{n} / 1.5 B_{n}\right)
$$

where $I_{g e o}$ is the geological accumulation index; $C_{n}$ is the concentration of element, and $B_{n}$ is the background value of element $n$.

The geological cumulative index can be divided into the following 7 levels: $I_{g e o} \leq 0$, the pollution level is 0 , which means unpolluted; $0<I_{\text {geo }} \leq 1$, the pollution level is 1 , which means unpolluted to moderately polluted; $1<I_{g e o} \leq 2$, the pollution level is 2 , which means moderately polluted; $2<I_{g e o} \leq 3$, the pollution level is 3 , which means moderately to heavily polluted; $3<I_{\text {geo }} \leq 4$, the pollution level is 4 , which means heavily polluted; $4<I_{g e o} \leq 5$, the pollution level is 5 , which means heavily to extremely polluted pollution; $5<I_{g e o} \leq 6$, the pollution level is 6 , which means extremely polluted.

1.3.2 Potential Ecological Risk Index 
The potential ecological risk index (PERI) was proposed by the Swedish scientist Hakanson (1980). It is mainly used to evaluate the degree of heavy metal pollution in the soil of the mining area. This method links the ecological effects, environmental effects and toxicology of heavy metals together. It can not only reflect the impact of various pollutants in sediments on the environment in a particular environment, but also use a quantitative method to classify the potential harm of heavy metals. PERI is currently the most widely used method in this type of research (Xiao et al. 2019; Lin et al.2018; Joanna et al. 2018; Jaime et al.2020; Amphalop et al.2020; Liu et al.2018). The calculation formula of the potential ecological risk index of a single heavy metal is:

$$
E_{i}=T_{i} *\left(C_{i} / S_{i}\right)
$$

Where $T_{i}$ is the toxicity response coefficient of element $\mathrm{i} ; C_{i}$ is the measured concentration of heavy metal; $S_{i}$ is the soil background value. The classification standards of PERI are classified as shown in Table 2:

Table 2 Pollution degree classification based on PERI

\begin{tabular}{cc}
\hline$E_{i}$ & Pollution degree \\
\hline$E_{i}<40$ & low \\
$40 \leq E_{i}<80$ & moderate \\
$80 \leq E_{i}<160$ & considerate \\
$160 \leq E_{i}<320$ & high \\
$E_{i} \geq 320$ & very high \\
\hline
\end{tabular}

1.4 Calculation of species diversity Index

Species diversity index refers to the ratio of the number of species to the number of individuals in a biological community, and is a method of describing the structural characteristics of the community through mathematical formulas. The evaluation of plant species diversity uses the following three indicators: Sics abundance index (Margalef index, R), Shannon-wiener diversity index(H), Pielou species evenness index(E)(Ma et al.2021):

$$
\begin{gathered}
\mathrm{R}=(\mathrm{S}-1) / \ln \mathrm{N} \\
\mathrm{H}=-\sum_{i=1}^{s}\left(P_{i} \ln P_{i}\right) \\
\mathrm{E}=H / \ln S
\end{gathered}
$$

Where $\mathrm{S}$ is the total number of species in the community, $\mathrm{N}$ is the total number of individuals observed, $P_{i}$ is the proportion of individuals of species $i$ to the total number of individuals in the community.

\subsection{Bioaccumulation Factor}

Bioaccumulation Factor ( BCF) (Wei et al.2004) is one of the important indicators to measure the content of heavy metals in plants. The calculation formula is:

$$
\mathrm{BCF}=C_{i} / C_{S}
$$

Where $C_{i}$ is the content of heavy metals in plants $(\mathrm{mg} / \mathrm{kg})$, and $C_{S}$ is the content of heavy metals in the soil $(\mathrm{mg} / \mathrm{kg})$.

1.6 Data statistics and analysis

All data were processed by EXCEL 2016 software. MATLAB 2017R software was used for statistical analysis and drawing.

\section{Results and discussion}

\subsection{Descriptive statistics}

Since the study area includes various types of land use, the concentration background values 
are also different. Therefore, the study areas are divided into three areas: As deposition area (A), the hillside (B) and the remediation field (C). According to the China Soil Environment Quality Risk Control Standard for Soil Contamination of Development (Agricultural) land of China (2018) (GB 15618-2018; GB 36600-2018), the background value of the pulp deposit area (A) adopts the risk screening value of the second type of development land, which is $60 \mathrm{mg} / \mathrm{kg}$. The background value of hillside (B) and remediation field (C) adopts the risk screening value of agricultural land, which is $25 \mathrm{mg} / \mathrm{kg}$. Table 3 and Table 4 present the risk screening and intervention values of soil As content in development land and agricultural land. Figure 2 shows the over-standard situation of soil points in the mining area. It can be seen intuitively in Figure 2 that all soil samples in area A exceeded the standard, and 10 points exceeded the control value; 10 samples in area B exceeded the risk of soil As contamination of agricultural land, and there were 8 points in area $\mathrm{C}$ that exceed the standard.

Table 5 provides the descriptive statistics of As contents and $\mathrm{pH}$ values of 50 sampling points and indicates that the $\mathrm{pH}$ values of the soil in the whole study area are greater than 8.1 , which is weakly alkaline. The respective range of soil As content in the three areas was: $54.00-231.00 \mathrm{mg} / \mathrm{kg}$, $13.30-100.00 \mathrm{mg} / \mathrm{kg}$, and $16.10-41.5 \mathrm{mg} / \mathrm{kg}$. The average value of As in area A was $150.7 \mathrm{mg} / \mathrm{kg}$ belonging to serious pollution, which was 1.08 times more than the intervention value of the second type land of development land. The average values of As in area B was $35.21 \mathrm{mg} / \mathrm{kg}$ belonging to heavy pollution, which exceeded 1.41 times the soil pollution risk screening value of agricultural land. The average values of $\mathrm{As}$ in area $\mathrm{C}$ was $25.88 \mathrm{mg} / \mathrm{kg}$ belonging to light pollution, which exceeded 1.03 times the soil pollution risk screening value of agricultural land. The coefficient of variation can be used to describe the degree of dispersion of the data values in the data set, which includes the average difference coefficient, the span coefficient, and the standard deviation coefficient. Due to the different pollution conditions in various regions, the average As content is not equal, which makes it impossible to compare the dispersion degree of each element through an absolute indicator such as standard deviation. Therefore, it is necessary to use the coefficient of variation to explain the dispersion degree. The standard deviation coefficient was selected in this paper. This is the ratio of the standard deviation of the group of data to the average value. The larger the value is, the more uneven the spatial distributions of the elements are. The coefficients of variation of soil As content in the six areas were ranked from large to small: B $>$ A $>$ C. Area B had the largest coefficient of variation and belonged to the strong variation type. It means that the As content in area B is unevenly distributed, and the source might be human activities.

Table 3 Risk filter and control values for soil contamination of agricultural land $(\mathrm{mg} / \mathrm{kg})$

\begin{tabular}{|c|c|c|c|c|c|c|c|c|}
\hline & \multicolumn{2}{|c|}{$\mathrm{pH} \leq 5.5$} & \multicolumn{2}{|c|}{$5.5<\mathrm{pH} \leq 6.5$} & \multicolumn{2}{|c|}{$6.5<\mathrm{pH} \leq 7.5$} & \multicolumn{2}{|c|}{$\mathrm{pH}>7.5$} \\
\hline & $\begin{array}{l}\text { Risk } \\
\text { screening } \\
\text { value }\end{array}$ & $\begin{array}{l}\text { interven } \\
\text { tion } \\
\text { value }\end{array}$ & $\begin{array}{l}\text { Risk } \\
\text { screening } \\
\text { value }\end{array}$ & $\begin{array}{l}\text { interven } \\
\text { tion } \\
\text { value }\end{array}$ & $\begin{array}{l}\text { Risk } \\
\text { screening } \\
\text { value }\end{array}$ & $\begin{array}{l}\text { interven } \\
\text { tion } \\
\text { value }\end{array}$ & $\begin{array}{l}\text { Risk } \\
\text { screening } \\
\text { value }\end{array}$ & $\begin{array}{l}\text { interven } \\
\text { tion } \\
\text { value }\end{array}$ \\
\hline $\begin{array}{l}\mathrm{A} \\
\mathrm{S}\end{array}$ & 40 & 200 & 40 & 150 & 30 & 120 & 25 & 100 \\
\hline
\end{tabular}

Table 4 Risk filter and control values for soil contamination of development land ( $\mathrm{mg} / \mathrm{kg})$

\begin{tabular}{lllll}
\hline & \multicolumn{2}{c}{ Risk screening values } & \multicolumn{2}{c}{ Intervention values } \\
\cline { 2 - 5 } & first type land & second type land & first type land & second type land \\
\hline As & 20 & 60 & 120 & 140 \\
\hline
\end{tabular}


Note: The first type of land mainly includes: residential land, public management and public service land, primary and secondary school land, medical and health land, social welfare land,

230 community park and children's park land, etc.; the second type of land mainly includes: industrial

231 land, Land for logistics and storage, land for roads and transportation facilities, land for public

232 facilities and land for squares, etc.

Table 5 As concentrations and $\mathrm{pH}$ of soil samples in different areas

\begin{tabular}{ccccccccc}
\hline Site type & & Item & Max & Min & Mean & $\begin{array}{c}\text { Coefficient of } \\
\text { variation }\end{array}$ & $\begin{array}{c}\text { Background } \\
\text { Value }\end{array}$ & Ratio \\
\hline \multirow{5}{*}{ Mining area } & \multirow{2}{*}{$\mathrm{A}$} & $\mathrm{As}(\mathrm{mg} / \mathrm{kg})$ & 231.00 & 54.00 & 150.70 & 0.37 & 60 & 2.51 \\
& & $\mathrm{pH}$ & 8.93 & 8.04 & 8.37 & & & \\
& & $\mathrm{As}(\mathrm{mg} / \mathrm{kg})$ & 100.00 & 13.30 & 35.21 & 0.71 & 25 & 1.41 \\
& $\mathrm{CH}$ & 8.56 & 5.33 & 8.19 & & & \\
& $\mathrm{As}(\mathrm{mg} / \mathrm{kg})$ & 41.50 & 16.10 & 25.88 & 0.28 & 25 & 1.03 \\
& $\mathrm{pH}$ & 8.40 & 7.53 & 8.13 & & & \\
\hline
\end{tabular}
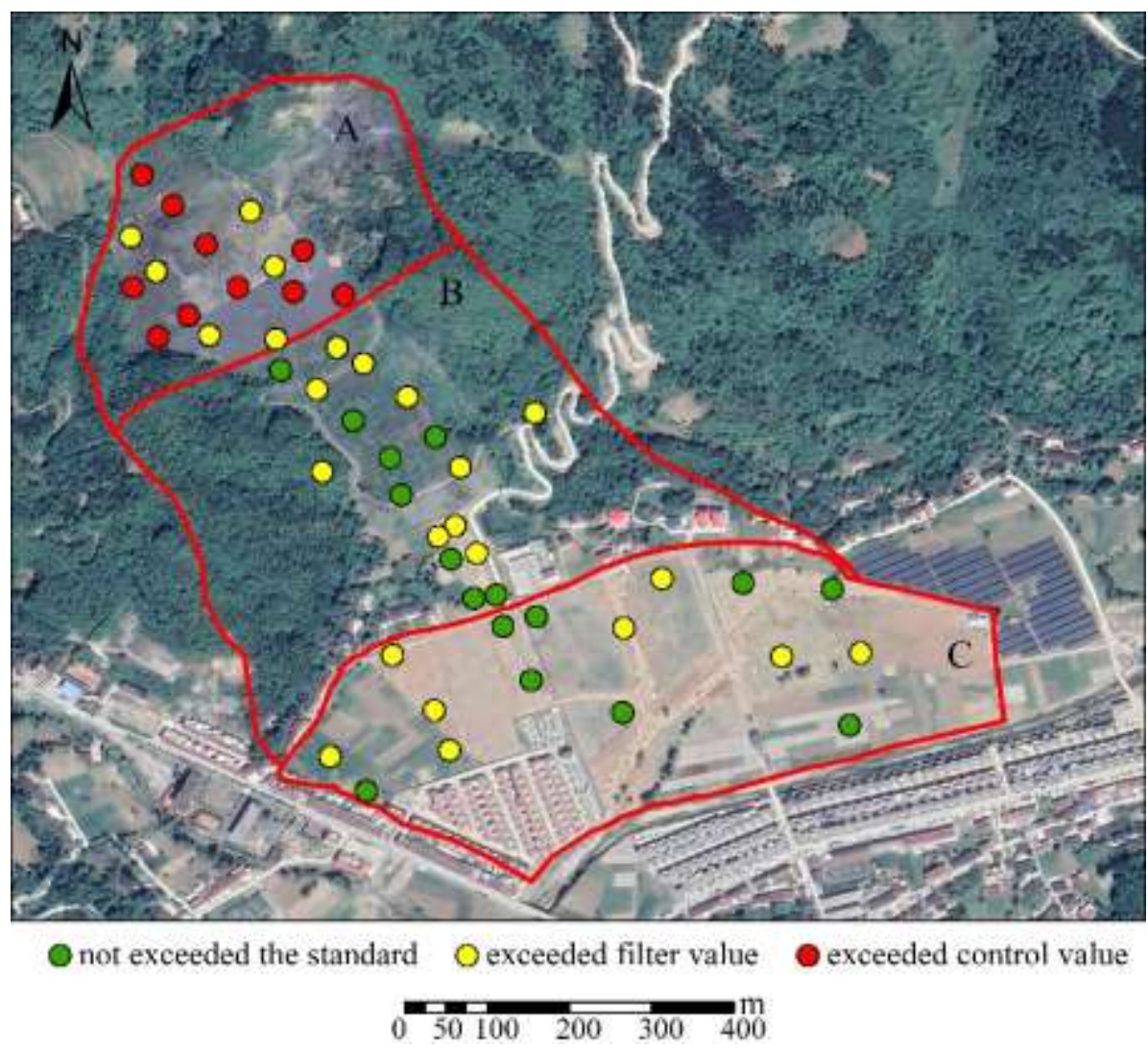

Figure 2 Excessive soil points in the mining area

2.2 Evaluation of heavy metal pollution degree of soil in mining area

\subsubsection{Index of geoaccumulation}

We took the background value of $11.2 \mathrm{mg} / \mathrm{kg}$ ( $\mathrm{Li}$ et al. 2020) of As in soil elements in China as $B_{n}$ to calculate the geoaccumulation index of As pollution in soil samples in mining areas, and the result is shown in Figure 3. Table 6 shows the accumulation index values of different areas in the mining area. As shown in Table 6, the geoaccumulation index values of soil As pollution in the mining area ranged from 0.34 to 3.78 , and the average value was 1.57 , which is moderately polluted. The average value of the heavy metal pollution coefficient in each region from high to low is $A>B>C$. The As pollution in the soil of the pulp deposition area (A area) is particularly serious, showing 
heavily polluted. Among them, there were 11 points in area A that are heavily polluted accounting for $22 \%$ of all points, and 6 points in area B were heavily polluted accounting for $12 \%$ of all points. It suggests that area A may be the source of pollution for the entire study area and even the entire village, threatening the ecological environment of the surrounding area.

Table 6 Calculation result of soil heavy metal accumulation index in the mining area

\begin{tabular}{cccc}
\hline Sampling area & \multicolumn{3}{c}{ Igeo } \\
\cline { 2 - 4 } & $\max$ & $\min$ & average \\
\hline $\mathrm{A}$ & 3.78 & 1.68 & 3.04 \\
$\mathrm{~B}$ & 2.57 & -0.34 & 1.06 \\
$\mathrm{C}$ & 1.30 & -0.06 & 0.62 \\
\hline
\end{tabular}
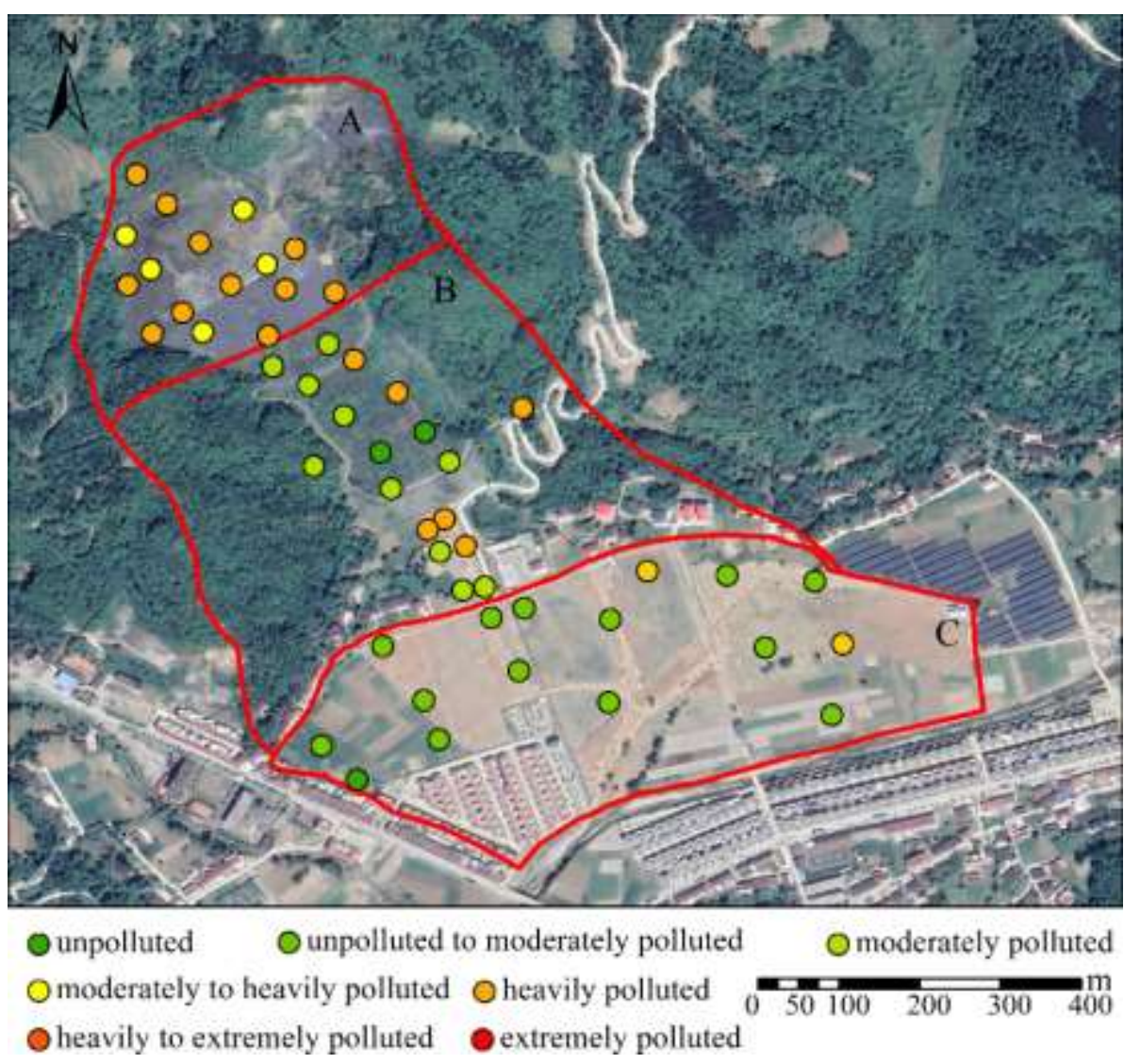

Figure 3. Heavy metal pollution degree of soil in mining area

\subsubsection{Potential ecological risk assessment}

Taking the toxicity response coefficient $T_{A S}=10$ (Zheng et al 2020a), and Table 7 shows the potential ecological risk index of soil As in the mining area. It can be seen from Table 7 that the potential ecological risk index values of soil heavy metals in the mining area ranged from 11.88191.07 with an average value of 63.03 , reaching a moderate degree of harm. The average value of the potential ecological risk index of heavy metals in each region decreased in the order of $A>B>C$, indicating that the ecological risk of heavy metals in the soil of the slurry deposition area (A area) reached a relatively high level. The potential ecological risk index of soil As in hillsides and remediation fields was less than 40 , showing a low pollution level. According to the evaluation results of the potential ecological risk index of soil As pollution in the mining area (Figure 4), it can be seen that $32 \%$ of the points belonged to considerate degree hazards, in which the proportion of high ecological risk reached $14 \%$ and all of them were in area $\mathrm{A}$, indicating that the soil As pollution 
in area A has been considerably serious. Generally, places far away from on-site pollution sources have lower potential ecological risks. A area is the closest area to the tailings dam break area, whose pollution is the most serious and the potential ecological risk index was the largest. It is also an important factor for the overall potential ecological risk of the site. due to rain erosion, B area is a hillside with a low soil As content. But there is a certain ecological risk because of a small amount of residue. $\mathrm{C}$ area has been performed artificial land treatments and a restoration project with the lowest soil As content, so the potential ecological risk index was the smallest.

Table 7 Calculation results of potential ecological risk index of soil heavy metals in mining area

\begin{tabular}{llll}
\hline Sampling area & \multicolumn{3}{c}{ Potential ecological risk index } \\
\cline { 2 - 4 } & $\max$ & $\min$ & average \\
\hline A & 191.07 & 48.21 & 134.55 \\
B & 89.29 & 11.88 & 31.44 \\
C & 37.05 & 14.38 & 23.11 \\
\hline
\end{tabular}

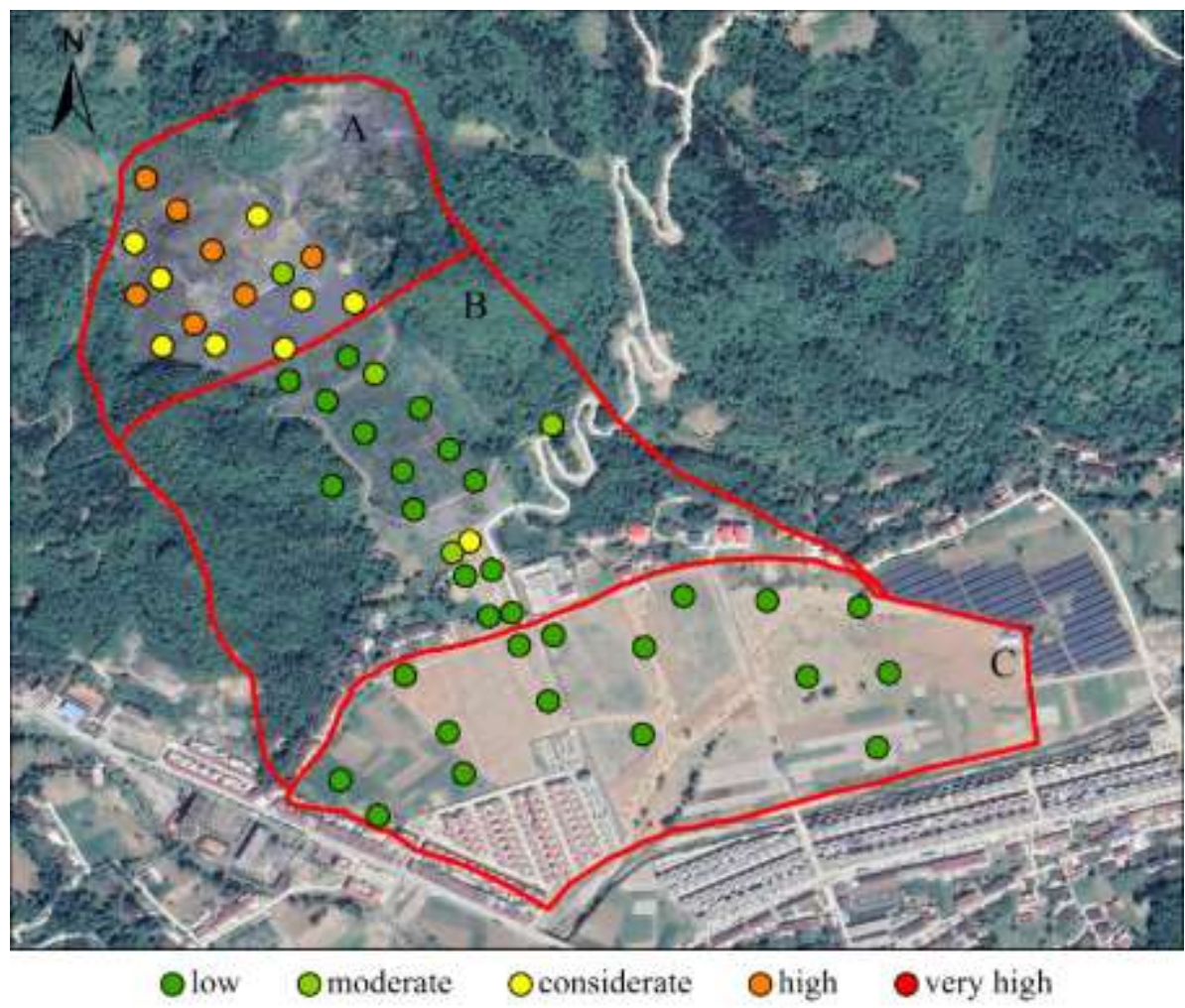

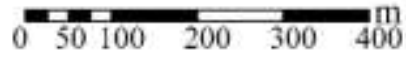

Figure 4 Potential ecological risk degree

2.3 Vegetation composition and heavy metal accumulation characteristics

\subsubsection{Vegetation composition in the mining area}

The area of the study area is $0.939 \mathrm{~km}^{2}$. The succession of vegetation communities is at an early stage, and the species composition is relatively diverse. There were 20 families and 39 species of plants in the surveyed plots (Table 8). The plants in the survey area were mainly herbaceous, and the more abundant plants are Phragmites communis (Cav.) Trin. ex Steud., Imperata cylindrica (L.) Beauv., Setaria viridis (L.) Beauv., Macleaya cordata (Willd.) R. Br., Erigeron annuus (L.) Pers. and other herbaceous plants. There were fewer shrubs and less coverage with only Periploca sepium Bunge, Lespedeza bicolor Turcz. Sophora davidii (Franch.) Skeels. The arbors were mainly 
artificially planted Robinia pseudoacacia L., as well as seedlings of Ailanthus altissima and Periploca sepium Bunge.

According to the survey results, leguminosae, gramineae and compositae plants accounted for the majority of plant species. There were 6 species of gramineae, accounting for $15 \%$ of the number of species, 8 species of compositae, accounting for $20 \%$ of the number of species, 9 species of Leguminosae accounting for $17.5 \%$ of the number of species, and other plant species account for the largest number of species. $49.5 \%$. It can be seen that in the process of vegetation restoration at this stage, gramineous, compositae and leguminous plants play an important role in the process of vegetation restoration at this stage, and they are also the dominant plant types in the early stage of natural succession in the restoration of vegetation communities in the mining area.

According to vegetation survey information such as the number of species, the number of individuals, and the distribution characteristics, the species abundance index, Shannon-Wiener index and Pielou evences index of the plant community are calculated to quantitatively reflect the species diversity characteristics of the plant community. The result is shown in Figure 5. The range of species abundance index was from 0.454 to 1.838 with an average value of 1.067 . The range of Shannon-Wiener index was from 0.117 to 1.833 with an average value of 1.244 . The range of Pielou evences index was from 0.450 to 0.921 with an average value of 0.697 . In general, the vegetation composition in the study area is relatively simple. Plant species diversity is a comprehensive evaluation index of species richness and species uniformity, which can reflect the stability of the community. The greater the diversity of the community is, the better the stability of the community is, and vice versa. The mining area is in the early stage of natural succession in vegetation restoration after the tailings dam broke. Thus, the species diversity is small and the stability of the vegetation community is poor.

Table 8 Main plant species and characteristics

\begin{tabular}{|c|c|c|}
\hline Family & Formal name & growth form \\
\hline \multirow{8}{*}{ Leguminosae } & Artemisia carvifolia Buch.-Ham. ex Ro & \\
\hline & Hort. Beng. & perennial herb \\
\hline & Robinia pseudoacacia L. & macrophanerophytes \\
\hline & Lespedeza bicolor Turcz. & shrub \\
\hline & Sophora davidii (Franch.) Skeels & shrub \\
\hline & Melilotus officinalis (L.) Pall. & perennial herb \\
\hline & Kummerowia striata (Thunb.) Schindl. & therophyte \\
\hline & Medicago Sativa Linn & perennial herb \\
\hline \multirow{7}{*}{ Gramineae } & Phragmites communis (Cav.) Trin. ex & \\
\hline & Steud. & perennial herb \\
\hline & Setaria viridis (L.) Beauv. & therophyte \\
\hline & Imperata cylindrica (L.) Beauv. & perennial herb \\
\hline & Digitaria sanguinalis (L.) Scop. & therophyte \\
\hline & Arthraxon hispidus (Thunb.) Makino & therophyte \\
\hline & Eriochloa villosa (Thunb.) Kunth & therophyte \\
\hline \multirow{3}{*}{ Compositae } & Aster subulatus Michx. & therophyte \\
\hline & Erigeron annuus (L.) Pers. & therophyte \\
\hline & Bidens pilosa $L$. & therophyte \\
\hline
\end{tabular}


Artemisia carvifolia Buch.-Ham. ex Roxb.

Hort. Beng.

therophyte

Ageratina adenophora (Spreng.) R.M.

King et H.Rob.

perennial herb

Sonchus arvensis $L$.

perennial herb

Inula japonica Thunb.

perennial herb

Artemisia argyi

perennial herb

\begin{tabular}{lll}
\hline Solanaceae & Solanum nigrum L. & therophyte \\
\hline Equisetaceae & Equisetum ramosissimum Desf & perennial herb \\
\hline Asclepiadaceae & Periploca sepium Bunge & shrub \\
\hline Simaroubaceae DC. & Ailanthus altissima & macrophanerophytes \\
\hline Chenopodiaceae & Chenopodium album L. & therophyte \\
\hline Polygonaceae & Polygonum L & therophyte \\
\hline Rubiaceae Juss. & Rubia cordifolia L. & perennial herb \\
\hline Moraceae & Humulus scandens (Lour.) Merr. & perennial herb \\
\hline Papaveraceae Juss. & Macleaya cordata $($ Willd.) R. Br. & perennial herb \\
\hline Valerianaceae & Patrinia scabiosifolia Fisch. ex Trevir. & perennial herb \\
\hline Labiatae & Mentha haplocalyx Briq. & perennial herb \\
\hline Pteridaceae E. D. N. Kirchn. & Pteris vittata L., & Pteridophyta \\
\hline Violaceae Batsch & Viola philippica & perennial herb \\
\hline
\end{tabular}

310
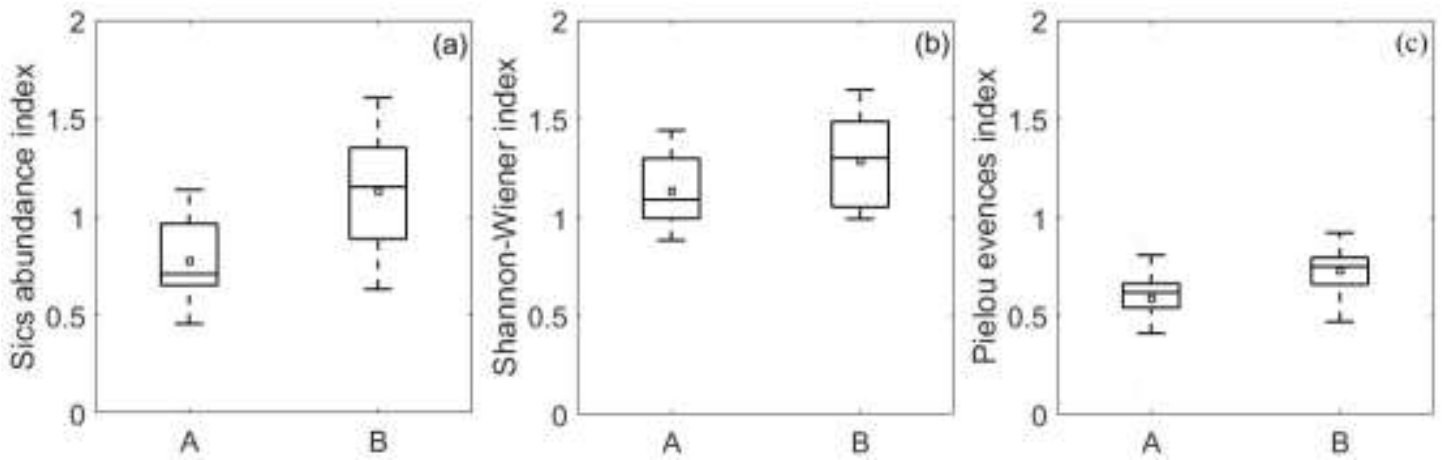

Figure 5 Vegetation Species diversity index in A and B area

2.3.2 Correlation between species diversity index and soil As pollution degree

The analysis of the species diversity index of the plant samples showed that the Sics abundance index, Shannon-Wiener index and Pielou evences index in the severely As-polluted areas (A area) was 1.018, 1.211 and 0.674 respectively, and in the non-As-polluted areas (B area) was 1.129, 1.287 and 0.726 respectively. It suggests that the vegetation species diversity of As-contaminated soil is less than that of uncontaminated soil, which means that the stability of vegetation community in polluted soil is worse than that of unpolluted soil. The Pearson correlation analysis results of the plant species diversity index of contaminated soil and the corresponding accumulation index (Table 9) showed that the accumulation index of As pollution had a significant negative correlation with the plant species diversity at the level of 0.05 , and the correlation coefficient was $-0.30,-0.25,-0.23$ respectively.

Table 9 Correlation between vegetation species diversity index and AS pollution index

Index Correlation coefficient




\begin{tabular}{ll}
\hline Sics abundance index & $-0.30 *$ \\
Shannon-Wiener index & $-0.25 *$ \\
Pielou evences index & $-0.23 *$ \\
\hline Note: $*$ is a significant correlation at the 0.05 level
\end{tabular}

2.3.3 Enrichment characteristics of As in dominant plants

In the pulp deposition area, the As content of the soil was relatively high, the plant species are few with poor growth status, and most of them are relatively short. The main vegetation types include: Periploca sepium Bunge, Robinia pseudoacacia L., Phragmites communis (Cav.) Trin. ex Steud., Setaria viridis (L.) Beauv., Imperata cylindrica (L.) Beauv., Erigeron annuus (L.) Pers. etc. The As content of hillside soil was low, and there are many kinds of plants with lush growth, whose height are relatively high. The main vegetation types include: Periploca sepium Bunge, Medicago Sativa Linn, Erigeron annuus (L.) Pers., Aster subulatus Michx., etc. After remediation measures such as ex-situ stabilization and stabilized backfilling, the As content of the remediation field soil has been relatively low. There are many types of plants in the remediation field. However, no crops have been planted since it is still in the recovery period. The main vegetation types include: Solanum nigrum L., Digitaria sanguinalis (L.) Scop., Chenopodium album L., Polygonum L, Setaria viridis (L.) Beauv., Macleaya cordata (Willd.) R. Br., etc. The dominant plants from various regions were collected and brought back to the laboratory to determine the As content in the plants. The results are shown in Table 10. It can be seen from Table 10 that the range of As content in plants in A area is $1.11-15.92 \mathrm{mg} / \mathrm{kg}$, with an average value of 6.75 . The range of As content in plants in $B$ area is $0.11-0.75 \mathrm{mg} / \mathrm{kg}$, with an average value of $0.32 \mathrm{mg} / \mathrm{kg}$. Among these dominant plants, the plants with strong As accumulating ability are Erigeron annuus (L.) Pers., Periploca sepium Bunge, Setaria viridis (L.) Beauv., Phragmites communis (Cav.) Trin. ex Steud., with BCF of 0.107, 0.050, 0.047 , and 0.036 , respectively. The enrichment coefficient is not large, indicating that As is not easy to migrate from the soil to the plants and be enriched.

Table 10 As content of plant -soil $(\mathrm{mg} / \mathrm{kg})$ and enrichment factor(BCF)

\begin{tabular}{|c|c|c|c|c|}
\hline area & Plant species & $\begin{array}{l}\text { Plant AS content } \\
(\mathrm{mg} / \mathrm{kg})\end{array}$ & $\begin{array}{l}\text { Soil AS content } \\
(\mathrm{mg} / \mathrm{kg})\end{array}$ & $\mathrm{BCF}$ \\
\hline \multirow[t]{6}{*}{ A } & Periploca sepium Bunge & 9.63 & 192 & 0.050 \\
\hline & Robinia pseudoacacia L. & 1.65 & 82.8 & 0.020 \\
\hline & $\begin{array}{l}\text { Phragmites communis (Cav.) Trin. ex } \\
\text { Steud. }\end{array}$ & 7.25 & 126 & 0.036 \\
\hline & Setaria viridis (L.) Beauv. & 4.95 & 105 & 0.047 \\
\hline & Imperata cylindrica (L.) Beauv. & 1.11 & 135 & 0.008 \\
\hline & Erigeron annuus (L.) Pers. & 15.92 & 149 & 0.107 \\
\hline \multirow[t]{8}{*}{ B } & Periploca sepium Bunge & 0.16 & 14 & 0.011 \\
\hline & $\begin{array}{l}\text { Artemisia carvifolia Buch.-Ham. ex } \\
\text { Roxb. Hort. Beng }\end{array}$ & 0.12 & 43.1 & 0.002 \\
\hline & Erigeron annuus (L.) Pers. & 0.19 & 19.9 & 0.009 \\
\hline & Aster subulatus Michx. & 0.11 & 38.5 & 0.002 \\
\hline & Ailanthus altissima & 0.35 & 27.6 & 0.012 \\
\hline & Macleaya cordata (Willd.) R. Br. & 0.21 & 21 & 0.010 \\
\hline & Solanum nigrum $L$. & 0.27 & 19.8 & 0.013 \\
\hline & Digitaria sanguinalis (L.) Scop. & 0.49 & 37.8 & 0.013 \\
\hline
\end{tabular}




\begin{tabular}{llll}
\hline Chenopodium album L. & 0.75 & 31.9 & 0.024 \\
Polygonum L & 0.53 & 33.2 & 0.016 \\
\hline
\end{tabular}

348

349

350

351

352

353

354

355

356

357

358

359

360

361

362

363

364

365

366

367

368

369

370

371

372

373

374

375

376

377

378

379

380

381

382

383

384

\section{Discussion}

\subsection{Potential analysis of phytoremediation}

In this study, we collected the dominant plant samples in the mining area, and calculated the enrichment factors. The results showed that the enrichment factors of Erigeron annuus (L.) Pers, Setaria viridis (L.) Beauv. and Periploca sepium Bunge for As were 0.107, 0.050 and 0.047 respectively, which indicated that they could adapt to the environment of As pollution and had a certain tolerance to As. Erigeron annuus (L.) Pers. and Setaria viridis (L.) Beauv.belong to Compositae and Gramineae respectively. These plants have developed roots, strong reproductive capacity, and strong ability to absorb soil water and nutrients. They are common weeds with strong vitality. Some studies have shown that Erigeron annuus (L.) Pers has a strong ability to repair $\mathrm{Cd}$ (Shao et al. 2020), and Setaria viridis (L.) Beauv. has a strong tolerance to as, Cr, Cd and other heavy metals (Ge et al. 2020, Lu et al, 2019, Liu et al, 2016). Periploca sepium Bunge is a kind of Asclepiadaceae plant, which has strong adaptability to soil. Once settled, it can quickly cover the surface, form dense roots underground, and improve the surrounding habitat. At the same time, Periploca sepium Bunge can provide favorable conditions for the settlement of other species and accelerate the process of vegetation restoration (Liang et al, 2008). Yanget al (2016) showed that Periploca sepium Bungehad a certain remediation potential for $\mathrm{Cu}, \mathrm{Cr}$ and other heavy metals.

The study area is located in the Qinling Mountains, which is on the diving line between North and South China and the $800 \mathrm{~mm}$ precipitation line. Qinling Mountains is rich in species resources. The annual average temperature is $15.6^{\circ} \mathrm{C}$, the annual average sunshine hours is 2040.4 hours, and the annual average precipitation is $953 \mathrm{~mm}$. The suitable climate conditions provide assistance for vegetation restoration in the mining area. Our field survey results also show that although the dominant plant species change little in 2019 and 2020, the vegetation coverage and growth in 2020 are better than that in 2019 at the same time in different years (Figure 6). Among them, Erigeron annuus (L.) Pers., Setaria viridis (L.) Beauv., and Periploca sepium Bunge are dominant species with good growth status, strong fecundity and large number, and can enrich arsenic in soil. According to the local climate environment and soil conditions, the selection of dominant plants that can enrich heavy metals to control heavy metal pollution is conducive to repairing the chain ecological damage caused by mining, restoring the mine ecological environment, accelerating the process of vegetation restoration, and promoting the sustainable development of the ecological environment in the mining area. In addition, the dominant plants screened in this experiment can be used as alternative plants for remediation of As pollution in mining area soil, laying a foundation for the next pollution remediation experiment of the project team. 


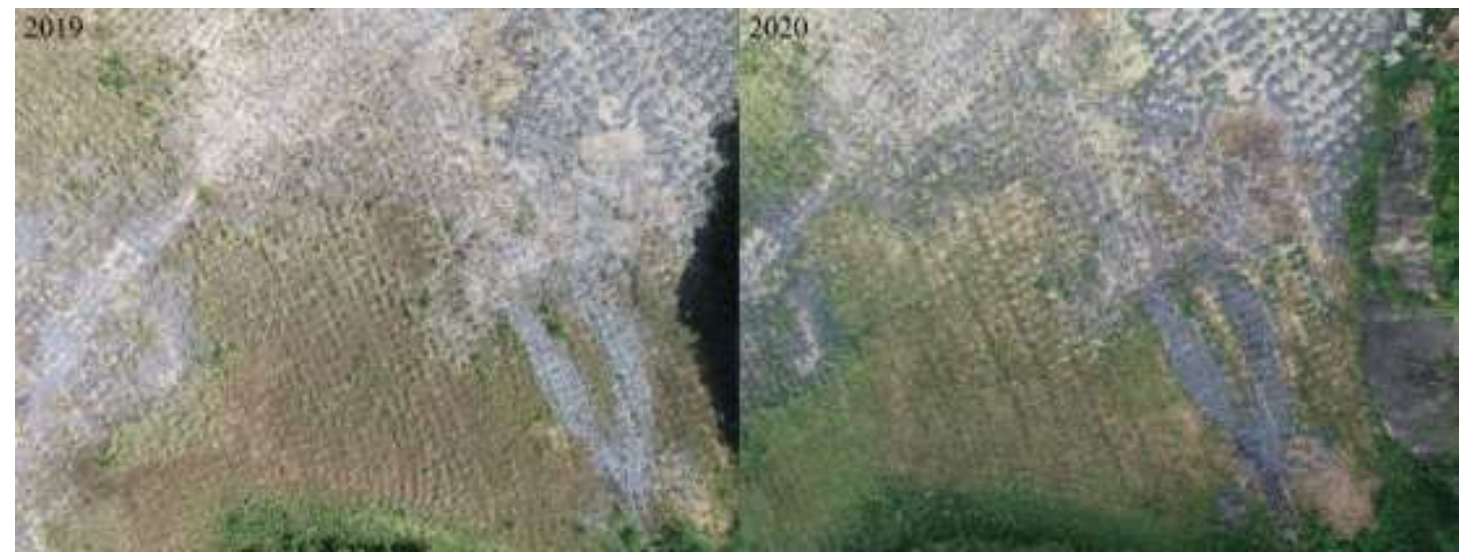

Figure 6 Comparison of vegetation coverage at the same location in the study area in 2019 (left) and 2020 (right).

\subsection{Limitations and future work}

In the evaluation of soil heavy metal pollution, due to the diversity of protection objects, exposure methods and standards, there are certain differences in soil environmental quality standard systems in various countries. Therefore, the evaluation standards for the degree of soil heavy metal pollution are also different in different regions, and there is no unified background value standard at home and abroad. Using different background values for the same object, such as national soil element background values, local soil element background values or national soil environmental quality risk values, will lead to different results. The soil heavy metal pollution in this study area is also the same. The calculation results of the national soil As element background value and the national soil environmental quality As risk value are not the same, and there is currently no unified regulation.

In addition, due to the limitations of research time and cost, we only analyzed the soil As pollution degree of an abandoned gold mine in Shangluo City and initially investigated the plant diversity and As content of the abandoned mine area. Compared with the same type of research, the plant samples are relatively single because of the small research area. In terms of heavy metal analysis in plants, the difference in the enrichment of heavy metals in various parts of the plant has not been analyzed. In future research, it is possible to appropriately increase the number of plots and analyze heavy metal enrichment in various parts of the plant. Further work needs to be done to select the dominant plant species for ecological restoration in mining areas through plant biomass and its effects on As enrichment and transfer. And pot experience could be conducted to explore the mechanism of As impact on plants (to quantify the impact of soil As pollution on plant physiological growth), and the remediation effect of dominant plants on soil As pollution in mining areas. Eventually, these research results may provide a basis for the ecological management of As contaminated areas.

\section{Conclusions}

The heavy metal pollution of soil and crops in metal mining areas and their surrounding areas has been highly concerned by countries all over the world, whi ch has become a "hot spot" issue studied by domestic and foreign scholars. For China, with the implementation of "ecological conservation and high-quality development of the Yellow River Basin" and "the ecological 
restoration project of mountains, rivers, forests, farmlands, lakes and grasses", the ecological restoration of mining areas is included in regional governance, which is vital for the implementation of the national ecological development strategy and the promotion of precision green mining in mines. Based on this, we conducted an investigation on soil As pollution and vegetation status in an abandoned gold mining area in Shaanxi Province. The main conclusions are as follows:

(1) Among the 50 sample points measured, $48 \%$ of the points' As contents exceeded the risk value of soil environmental quality, $20 \%$ of the points' As contents exceeded the control value, and all of which were located in area A. The coefficients of variation of soil As content in each region decreased in the order of $\mathrm{B}$ area $>\mathrm{A}$ area $>\mathrm{C}$ area.

(2) The average geoaccumulation index of soil As pollution in the mining area was 1.57, belonging to the moderate pollution degree, and the pollution degree in area $\mathrm{A}$ is the most serious, indicating the severe pollution; The average value of the soil heavy metal potential ecological risk index was 63.03, and the ecological risk was moderate. The potential ecological risk index of area A was the largest. It is also an important factor that causes the overall potential ecological risk of the site and threatens the ecological environment of the surrounding area.

(3) The survey results show that the vegetation composition in the study area is relatively simple. The composition of the plant community was dominated by herbaceous plants. Gramineae, compositae, and leguminosae plants are the main plant types in the restoration of vegetation communities in this mining area due to the strong dispersal ability of these three types of plant seeds and the stronger adaptability of the plants themselves. The average value of the Sics abundance index, Shannon-Wiener index, Pielou evences index was 1.067, 0.244 and 0.697 respectively, and the plant species diversity in A area was smaller than B area.

(4) Different plants have great differences in As accumulation capacity. Among the dominant plants in the mining area, the difference of As content between Erigeron annuus (L.) Pers. in A area and Aster subulatus Michx in area B was 144.73 times, indicating that the migration and accumulation of As by different plants are quite different. The content of natural As in plants was less than $2.00 \mathrm{mg} / \mathrm{kg}$. But the As content in the plants in the mining area is more than $2.00 \mathrm{mg} / \mathrm{kg}$ in Periploca sepium Bunge, Phragmites communis (Cav.) Trin. ex Steud., Setaria viridis (L.) Beauv., and Erigeron annuus (L.) Pers., accounting for $86.61 \%$ of the total, indicating that these four plants can be considered as As-tolerant plants used in the next step of restoration experimental research. This result has important guiding significance for the restoration and reconstruction of the vegetation ecosystem in the mining area.

Acknowledge: This study was funded by the Opening fund of the Key Laboratory of Degraded and Unused Land Consolidation Engineering, Ministry of Land and Resources (Program No. SXDJ2017-9). and the Opening fund of Shaanxi Key Laboratory of Land consolidation (Program No. 2018-ZZ03).

Authors Contributions: RC: Formal analysis, Investigation, Methodology, Software, Visualization, Writing - original draft; LH: Conceptualization, Data curation, Funding acquisition, Investigation, Writing - review \& editing, Project administration, Resources; ZL: Formal analysis, Investigation, Supervision; YZo: Supervision, Validation; SC: Investigation, Software, Writing review \& editing; LL: Investigation, Writing - review \& editing; RL: Supervision, Visualization; LX: Validation. All authors read and approved the final manuscript.

Data availability The datasets used or analyzed during the current study are available from the 
corresponding author on reasonable request.

Ethical Approval: Not applicable.

Consent to Participate: Not applicable.

Consent to Publish: Not applicable.

Competing interests: The authors declare no competing interests.

\section{Reference}

Alka S, Shahir, Ibrahim N et al (2020) Arsenic removal technologies and future trends: a mini review. J. Clean Prod. 278(2): 123805. https://doi.org/ 10.1016/j.jclepro.2020.123805.

Amphalop N, Suwantarat N, Prueksasit T et al (2020) Ecological risk assessment of arsenic, cadmium, copper, and lead contamination in soil in E-Waste separating household area, Buriram Province, Thailand. Environ Sci Pollut Res 27, 44396-44411 https://doi.org/10.1007/s11356-020-10325-x.

Bourliva A, Papadopoulou L, Aidona E et al (2017) Characterization and geochemistry of technogenic magnetic particles (TMPs) in contaminated industrial soils: Assessing health risk via ingestion. Geoderma 295: 86-97. https://doi.org/10.1016/j.geoderma.2017.02.001.

Chen TB, Wei CY, Huang ZC et al (2002) Arsenic hyperaccumulator plant pteris vittata L and its arsenic accumulation characteristics Chin. Sci. Bull. 47 (3): 207-210 (in Chinese).

Deng CX, Xu FL, Yue M (2019) Characteristics of heavy metal pollution of farmland soil in a pyrite tailings area in Anhui. Journal of Safety and Environment 19(01):337-344 (in Chinese).

GB 15618-2018. Soil environmental quality-risk control standard for soil contamination of agricultural land; ministry of ecology and environment of the people's republic of China, Beijing, $\quad 2018 . \quad$ Available online: http://www.mee.gov.cn/ywgz/fgbz/bz/bzwb/trhj/201807/t20180703 446029.shtml

GB 36600-2018. Soil environmental quality-risk control standard for soil contamination of a development land; Ministry of ecology and environment of the people's republic of China, Beijing, $\quad$ China, Available online: http://www.mee.gov.cn/ywgz/fgbz/bz/bzwb/trhj/201807/t20180703 446027.shtml

Ge YY, Qiao Q, Zhang P et al (2020) Heavy metal enrichment characteristics of dominant plants naturally growing on chromium residue dump site in southern Shanxi. Environmental Pollution \& Control. 42(7):833-837(in Chinese).

Hakanson L (1980) An ecological risk index for aquatic pollution control. a sedimentological approach. Water Res. 14 (8): 975-1001. https://doi.org/10.1016/0043-1354(80)90143-8.

Jaime TG, Isabel GM, Eduardo S et al (2020) Advanced determination of the spatial gradient of human health risk and ecological risk from exposure to $\mathrm{As}, \mathrm{Cu}, \mathrm{Pb}$, and $\mathrm{Zn}$ in soils near the ventanas industrial complex (Puchuncaví, Chile). Environ. Pollut 258:113388. https://doi.org/10.1016/j.envpol.2019.113488.

Joanna BK, Ryszard M, Michał G, Tomasz Z (2018) Pollution indices as useful tools for the comprehensive evaluation of the degree of soil contamination-A review. Environ. Geochem. Health 40: 2395-2420. https://doi.org/10.1007/s10653-018-0106-Z.

Li K, Peng M, Yang Z et al (2020) Trace metals pollution and health risks for planning area soils of 193 Chinese cities. Environmental Science 41(04):1825-1837. https://doi.org/10.13227/j.hjkx.201909142. (in Chinese)

Liang JH, Liu PP, Chen Z et al (2018) Rapid evaluation of arsenic contamination in paddy soils 
using field portable X-ray fluorescence spectrometry. Journal of Environmental Sciences, 64, 345-351. https://doi.org/10.1016/j.jes.2017.11.020.

Liang XM, Zhang XP (2008) Perip Selocapium Bge-a Muli-purpose Native Tree. Modern Agricultural Sciences. (12):43+55(in Chinese).

Lin WT, Wu KM, Lao ZL (2018) Assessment of trace metal contamination and ecological risk in the forest ecosystem of dexing mining area in northeast Jiangxi Province, China. Ecotox. Environ. Safe. 167: 76-82. https://doi.org/10.1016/j.ecoenv.2018.10.001.

Liu G, Shi Y, Tian HJ et al (2018) Soil pollution characteristics and ecological risk assessment of As at a largescale arsenic slag-contaminated site. Environmental Science 39(12): 5639-5646. https://doi.org/10.13227/j.hjkx.201804087.

$\mathrm{Lu}$ JZ, Lu HW, Li J et al (2019) Multi-criteria decision analysis of optimal planting for enhancing phytoremediation of trace heavy metals in mining sites under interval residual contaminant concentrations. Environmental Pollution.255(2):

113255 . https://10.1016/j.envpol.2019.113255

Luo GF, Han ZW, Xiong J et al (2021) Heavy metal pollution and ecological risk assessment of tailings in the Qinglong Dachang antimony mine, China. Environ Sci Pollut Res. https://doi.org/10.1007/s11356-021-12987-7.

Ma K, Shi X, You XG et al (2021) Relationship of the heavy metal distribution in sediments to vegetion diversity and macroinvertebrate communities in riparian wetlands. Acta Ecologica Sinica (05):1-10. $\quad$ http://kns.cnki.net/kcms/detail/11.2031.Q.20201231.1618.059.html.(in Chinese)

Ma L, Komar K, Tu C et al (2001) A fern that hyperaccumulates arsenic. Nature 411: 438. https://oi.org/10.1038/35078151.

Manoj SR, Karthik, Kadirvelu K et al (2020) Understanding the molecular mechanisms for the enhanced phytoremediation of heavy metals through plant growth promoting rhizobacteria: A review. J. Environ. Manage. 254: 109779. https://doi.org/10.1016/j.jenvman.2019.109779.

Meharg, AA (2003). Variation in arsenic accumulation: hyperaccumulation in ferns and their allies. New Phytol. 157 (1): 25-31. https://doi.org/10.1046/j.1469-8137.2003.00541.x.

Müller G (1969) Index of geoaccumulation in sediments of the Rhine River. Geojournal 1969, 2 (3): 108-118.

Nateewattana J, Trichaiyaporn S, Saeouy M et al (2011) Phytoremediation of Arsenic in submerged soil by wetland plants. Int. J. Phytoremediat. 13 (1):35-46. https://doi.org/10.1080/15226511003671320.

Rodriguez-Lado L, Sun G, Berg M et al (2013) Groundwater arsenic contamination throughout China. Science 341 (6148): 866-868. https://doi.org/10.1126/science.1237484.

Shao HQ, Zhang YW, Qu C et al (2020) Analysis of heavy metal contamination in the soil and enrichment capabilities of terrestrial plants around a typical vanadium smelter area. Chinese Journal of Engineering. 42(03):302-312(in Chinese).

Srivastava, Ma LQ, Santos J G (2006). Three new arsenic hyperaccumulating ferns. Sci. Total Environ. 364 (1-3): 24-31 https://doi.org/10.1016/j.scitotenv.2005.11.002.

Wang JX, Xing Y, Li P et al (2018) Chemically-assisted phytoextraction from metal(loid)s-polluted soil at a typical carlin-type gold mining area in southwest China. J. Clean Prod. 189(10):612619. https://doi.org/10.1016/j.jclepro.2018.04.082.

Wei CY, Chen TB, Huang ZC et al (2002) Cretan Brake (Pteris cretica L.): an arsenic-accumulating 
plant. Acta Ecologica Sinica 22 (5): 777-778(in Chinese).

Wei SH, Zhou QX, Wang X et al (2004) A newly discovered cadmium hyperaccumulator plant Solanum nigrum L Chin. Sci. Bull. 49(24): 2568-2573. https://doi.org/10.3321/j.issn:0023074X.2004.24.013.

Xiao R, Guo D, Amjsd AL, Mi SS et al (2019) Accumulation, ecological-health risks assessment, and source apportionment of heavy metals in paddy soils: A case study in Hanzhong, Shaanxi, China. Environ. Pollut. 248: 349-357. https://doi.org/10.1016/j.envpol.2019.02.045.

Xiao TF, Hong B, Yang ZH et al (2001) Hydrogeochem istry of arsenic and its environmental effects. Bulletin of geological science and technology (01), 71-76 (in Chinese).

Yan HL, Gao YW, Wu, LL et al (2019) Potential use of the pteris vittata arsenic hyperaccumulationregulation network for phytoremediation. J. Hazard. Mater.368:386-396. https://doi.org/10.1016/j.jhazmat.2019.01.072.

Yang YH, Zhu YH, Ru GX et al (2016) Investigation of the heavy metal concentration in the soil and indigenous plants around coal gangue dump. Journal of Anhui Agricultural University. 43(02): 276-281(in Chinese).

Yuan X, Xue N, Han Z (2021). A meta-analysis of heavy metals pollution in farmland and urban soils in china over the past 20 years-science direct. Journal of Environmental Sciences, 101, 217-226. https://doi.org/10.1016/j.jes.2020.08.013.

Zhang NM, Xia YS, Chen BD et al (2019) Mycorrhiza and iron chemical remediation of arsenic contaminated soil. Science Press, Beijing.

Zheng XJ, Chen M, Wang JF et al (2020a) Ecological risk assessment of heavy metals in the vicinity of tungsten mining areas, southern Jiangxi Province. Soil and Sediment Contamination: An International Journal. 29(6):665-679. https://doi.org/10.1080/15320383.2020.1763912.

Zheng Y (2020b) Global solutions to a silent poison. Science 368 (6493): 818-819. https://doi.org/10.1126/science.abb9746.

Zou XL, Zhou Y (2004) Arsenic (As) uptake, accumulation and translation by willows in wetlands. Journal of Jiangxi University of Science and Technology. 35(03): 7-12 (in Chinese). 